\title{
Heirs to world culture 1950-1965 An introduction
}

\author{
Jennifer Lindsay
}

In the early 1990s I visited Banda Neira, the centre of the fabled 'spice islands', arguably where the history of colonialism in the Indies began, but also a revered site of nationalist history where in 1936 Hatta (later Indonesia's first vice-president) and Sjahrir (later Indonesia's first prime minister) spent six years in exile until released by the Japanese in $1942 .{ }^{1}$ In the main square was a small monument to Indonesia's independence - the kind one finds all over the archipelago. This one struck my attention though - because the date on it was not the usual 17-8-1945, the date of the proclamation of independence that is so deeply etched into the Indonesian psyche as the birth of the nation, but 27-12-1949, the date of the official transfer of sovereignty from the Dutch, when Indonesia's independence was recognized internationally.

The December 1949 date on the monument in Banda Neira indicates that until relatively recently there was in Indonesia an element of fluidity about what was perceived as the birth of the nation. ${ }^{2}$ Today, the generation that as young adults experienced the events of those dates is passing, and 17 August 1945 has acquired mythic status as Indonesia's birthday. But while merdeka (independence) was patchy over the archipelago from August 1945-December 1949, (Banda, for instance, was not part of the ter-

1 I would like to express my sincere thanks to my co-editor, Maya Liem, together with Tony Day and Keith Foulcher for their input and helpful comments when drafting this introduction. I also thank Henk Schulte Nordholt, co-research leader of the 'In Search of a Lost Legacy' project, whose summary at the second workshop held in Jakarta in October 2009 helped shape many ideas here. My deepest thanks to all the participants at both workshops for their stimulating contributions to the discussions that they will find echoed in this introduction. And finally, thanks to the two anonymous reviewers of the manuscript who made excellent suggestions for improvement. 2 It might also be seen as subversive local comment highlighting Sjahrir's role in the diplomatic resolution of Indonesia's independence over that of Soekarno as proclamator. Sjahrir is particularly identified with Banda Neira, having adopted three Banda children, including the late Des Alwi. 
ritory controlled by the Indonesian republic), by the dawn of 1950 Indonesia's nationhood was a legal fact and Indonesia was officially recognized internationally as a nation among other nations. The fighting had stopped and negotiations ceased, and the business of filling in what 'merdeka' meant now began in earnest. Culture was at the core of that process.

Over the next 15 years, until the coup and counter-coup of 30 September-1 October 1965 - the period that frames the research presented in the essays in this volume - Indonesia faced enormous challenges, first and foremost that of forging a sense of nationhood to outlast the euphoria of the achievement of sovereignty. In 1950, there was little holding the new nation together beyond goodwill. Administratively, Indonesia inherited a colonial state with its civil service designed for the efficient management of a colonial economy. Politically, it inherited a Dutch-devised and imposed federal system that in mid 1950 was overturned in favour of the unitary republic long envisaged by the Indonesian nationalist movement. Economically, it inherited an extract economy developed for colonial interests (Taufik Abdullah 2009; Schulte Nordholt 2009) and a huge debt to be repaid to the Netherlands, as stipulated by the Round Table Conference negotiations in late 1949 (Gouda and Brocades Zaalberg 2002). Culturally, Indonesia was held together primarily by its national language, Indonesian Malay, which the nationalist movement had named 'Bahasa Indonesia' and declared the 'language of unity' back in 1928, but which received its real boost during the Japanese occupation (1942-1945) when the speaking, teaching and publication of Dutch had been prohibited. Socially, the nation inherited from the 1945-1949 period a shared sense of revolution and change, and faith in the future (Reid 1974). But in order to understand what really held the nation together after December 1949, once independence had been finally recognized and the harsh realities of political and economic life set in, one has to look at cultural expression of the time. There, the overriding concern with 'Indonesianness' leaps to the fore. Despite various and conflicting ideological approaches about what kind of culture Indonesia should have, there was a common conviction that 'being Indonesian' was an issue of culture.

THE $195^{\circ-1} 965$ PERIOD

The 1950-1965 time span of Indonesian history can be seen as many periods within a period, depending on the lens used, (decol- 
onization; federalism to unitarism; regional conflict; constitutional democracy; political factionalism; autocratic rule; international relations; economic decline; Cold War interventions). But in one significant respect 1950-1965 is a single period - namely in the way our ideas about it have been shaped by the way it ended. It is this retrospective vision that the essays in this book focussing on cultural history set out to challenge.

The ending of the story, with all its unanswered questions, is relatively well known, and remains a sensitive topic in Indonesia over four decades later, despite the fact that since the fall in 1998 of Soekarno's deposer and successor, President Suharto, people in Indonesia are finally able to speak and write more openly about those events. On the night of 30 September-1 October 1965 in Jakarta, six generals were kidnapped and murdered by a group (comprising members of the palace guard, some army battalions and civilian communist youth) that called itself 'the 30th September Movement' and claimed its actions were to intercept a coup by a CIA-backed 'Council of Generals'. The '30th September Movement' was immediately countered by anti-communist army forces led by General Suharto who assumed command when these forces regained control of Jakarta. The coup was blamed fully on the Communist Party (Partai Komunis Indonesia or PKI; the coup became known in Indonesia henceforth as G30S-PKI), and a violent purge followed over the following four months, with mass killings of at least half a million people as communists and leftist sympathizers. ${ }^{3}$ A witch-hunt for anyone of perceived leftist persuasion continued over the following years, resulting in imprisonment without trial for hundreds of thousands more. Artists, cultural practitioners and intellectuals who had or were perceived to have had communist or leftist connections were also hunted, killed, imprisoned, or silenced through trauma and fear. ${ }^{4}$

But what if we try to look at the tensions and conflicts of the 19501965 period not backwards, from when they violently exploded in late 1965 , but as they were at the time, or more precisely at various times over that 15-year period, when people were looking forward,

3 The literature on these events is extensive. See further (and the bibliographies therein): on the coup and counter coup, John Roosa (2006); on the killings, Robert Cribb (1990) and Greg Fealy and Katharine McGregor (2010); on the powerful mythmaking and historical blackout during Suharto's New Order, Ariel Heryanto (1999).

4 Hersi Setiawan (1995) has written about the life in prison of many of these detainees in Buru. A recent Indonesian publication that recounts the detention without trial for seven years of a Sundanese traditional singer, merely because of her performance history at Soekarno's presidential palace at Cianjur and the fact that she once sang at a public PKI event, see Nani Nurani Affandi 2010. 
not backwards? Certainly, for at least the first decade, the differences, tensions and conflicts between intellectual and cultural groups can then be seen as the rigorous debate of young men (for the spokespersons were almost entirely men) jostling and testing new ideas and their own newfound positions on the stage of the new republic; such conflict was part of the fabric of the time, and had roots in the 1930s and 1940s. ${ }^{5}$ People did not know then, of course, how the increasingly rigid and polarized positioning of ideas would explode, even if by early 1965 - with Soekarno's deteriorating health, the heat of Cold War politics, domestic jockeying for power, autocratic government, conflict over land reform, censorship, and the thorough politicization of language (as the occasional 'alphabet soup' of acronyms in this book attests) - it was clear that something had to give. From 1963, things began to get nasty. The Left was in the ascendant, and hounded those of different persuasion. Artists and cultural practitioners sought alignment (and protection) with political groups such as the Nahdlatul Ulama (NU, Revival of Islamic Scholars) or the Partai Nasional Indonesia (PNI, Indonesian National Party). Debates were no longer relatively innocent combatant exchanges of ideas between energetic young men, but became more inclined towards vicious personal vilification. And divisions and tensions were not only between broad ideological 'camps', but also within them: not only between the PKI and NU, or NU and PKI, but also within NU (Fealy and McGregor 2010), and within LEKRA (Lembaga Kesenian Rakjat, the Communist Party-affiliated Institute of People's Culture) and the PKI (Bodden, this volume). The centre could not hold.

Given the tragic events of late 1965 and the bloodbath and eruption of violence directed against communists or those perceived to be leftist sympathizers following the events of 30 September-1 October, it is not surprising that the entire 1950-1965 period generally has been seen (by Indonesian and non-Indonesians alike) in terms of a trajectory towards that tragic end point: the economy failing; the decline of constitutional democracy ${ }^{6}$; an increasingly autocratic leader; the crushing of regional autonomy; centralization of power; intellectual and cultural polarization between the Left and the Right, and the Cold War looming over all. The power of this picture of decline owes much to General (later President) Suharto's regime that followed (1966-1998),

5 See Hersri Setiawan's essay (2003) 'Tentang Lekra' (On Lekra) for an account of the emergence of Lekra in 1950 from cultural practice and earlier debates of the 1930s and 1940s.

6 Indeed, Herbert Feith's influential study of this period is titled 'The decline of constitutional democracy in Indonesia' (Feith 1962). 
which effectively portrayed the previous period as a path to disaster to justify its own usurping of power. However, we must remember that Soekarno himself contributed to this picture. He had also portrayed the early 1950-1957 period as another path to disaster, using the failure of constitutional democracy as justification for instituting 'Guided Democracy'.

Writing on culture of the Soekarno period has also tended to focus on the way things ended up in 1965, and this picture has then been applied to the 1950 s and early 1960 s as a whole. Claire Holt (1967) is a stellar exception, but her book discusses art in this period as part of a much broader historical survey. Michael Bodden (2010) has recently given a fresh, more nuanced picture of the political background to leftist cultural activity of the period. Generally, however, there has been intense interest in divisions between cultural camps rather than to any connections between them, and the focus on 'culture' has been predominantly where divisions became most marked - in the field of Indonesian literature and to a lesser extent, painting. ${ }^{7}$ This was the arena of high culture, (even though often couched in the name of 'the People') where the debate about national direction for art was most articulated. The world of popular culture during the Soekarno period, however, has largely escaped notice, except for film, where the focus has been more on divisions and ideological conflict in the field of Indonesian production, particularly in the early 1960s, rather than on broad popular consumption (Salim Said 1991; Sen 1994).

A scholarly bias towards literature and written sources, coupled with a retrospective post-1965 lens, has resulted in the portrayal of intellectual and cultural life of the whole early period of the Indonesian republic as one of polarized conflict of Left versus Right, little nuanced by the complexity of internal relationships within any 'left' or 'right', and with virtually no attention paid to other cultural movements, for instance the activities of the various Muslim cultural organizations and to their links within the international Muslim world. The conflict that erupted in 1963 between LEKRA cultural workers and the Manifes Kebudayaan (Cultural Manifesto) signatories has been taken as the ultimate symbol of cultural conflict, portrayed as a polarized clash between ideologies of engaged art versus 'art for art's sake' and then applied retrospectively to the entire 15-year period and to all art and artists. To begin to understand the 1950 s and early 1960s, we must attempt to look at the period in its own terms, and not in retrospect from a 1965 perspective. We need

7 For literature, see Foulcher 1986, 1993; Maier 1987. On visual art, see Wright 1994; Spanjaard 1998; Agus T Dermawan and Wright 2001; Amir Siddharta 2006. 
to ask new questions. How did Indonesian artists and intellectuals interrelate? How did their ideas and activities stimulate each other? How did they relate to the world outside? What was the interaction between exposure to the world and cultural developments back home? What was daily cultural life like? How did areas outside of Java or Jakarta relate to the cultural debates and divisions there? What did 'national culture' mean locally over Indonesia over this period, and how was commitment to it influenced by local events? The writers in this volume have tried to address these and other questions by seeking out fresh data and fresh subjects, and by trying to look at Indonesia's cultural history from 1950-1965 with fresh eyes and new approaches to better understand how the world and Indonesia might have looked to various Indonesian cultural actors in various places and at various times back then. In so doing, they have found the situation more complex and fluid than hitherto understood. More than differences and divisions among artists and intellectuals, or despite them (for they were, indeed, often bitter and very real, particularly in the early 1960s), they have discovered there was an overriding common commitment to the future, to the nation, to Indonesian culture, and to what that might be.

Culture is crucially important to understanding Indonesia at this time. The importance the Republic placed on culture in building the nation is shown by the fact that even in the chaotic period of 1948, when the Republic was in disarray, its territories whittled back to Aceh, parts of Sumatra and Central Java, and when internal tensions were about to erupt in the September communist uprising in Madiun, the government organized the first Cultural Congress, which was held in Magelang in August with President Soekarno, Vice President Hatta and General Sudirman all attending both the opening and closing ceremonies, and the Minister for Education, Training and Culture (Ali Sastroamidjojo) participating throughout. Yet culture has often been treated as peripheral to the 'real' business of political history. ${ }^{8}$ This is partly because those writing specifically on culture of the period have also tended to see cultural history in narrow terms; focussing on Indonesian literature, or LEKRA, or the Cultural Manifesto debate and cultural ideologies of the early 1960s, with little attention to the overall place of culture in the nation, to the wider world of international cultural

8 For instance, neither Feith (1962) nor Anderson (1972) include the word 'culture' as the other part of the portfolio of the Ministers entrusted with it. The importance the Indonesian Republic placed on culture is reflected in the fact that it was linked with education from the very first cabinet. Ki Hadjar Dewantara was Indonesia's first Minister for Education, Training and Culture (Pendidikan, Pengajaran dan Kebudayaan), from September-November 1945. 
traffic, to Indonesia beyond Jakarta or Java, or to popular culture and other art forms beyond literature.

But the 1950s and early 1960s was a time when Indonesia's links with the world and its nationhood were vigorously negotiated on the wide cultural front. It was a heady time of nation building. Culture was at the very heart of relations between people, which was what nation building was most crucially about, as artists and intellectuals in the young republic reflected upon, engaged and experimented with, and argued vigorously about what was linking and dividing them and making them 'Indonesian'. And the international setting was right at the heart of thinking of the nation among other nations. The inter-relationship between Indonesia's cultural traffic abroad and the developments at home during the 1950-1965 period is what the essays in this volume together address.

POLITICAL MAPPING

The major political events of the 15 years from 1950 until the 1965 coup that culminated in the toppling of Soekarno and the elimination of the Left have been well documented (Feith 1962; Ricklefs 2001; Taufik Abdullah 2009). Commonly, the 1950-1965 period has been divided into two: 1950-1957 as the time of constitutional democracy including Indonesia's first general election in 1955; and 1957-1965 as the time of Guided Democracy, with 1957-1958 marking a watershed with serious outbreaks of regional rebellion, political crisis, more autocratic government, increased prominence of the Left in political, social and cultural life, and the nationalization of Dutch enterprise. Taking 1950 as the beginning point blurs many continuations with the 1945-1949 period, including the negotiations and conflicts that marked the staggered transition from the federal United States of Indonesia to the unitary republic by August 1950, which ensconced Soekarno as political leader and marginalized previously important leaders such as Sjahrir and Hatta (Gouda and Brocades Zaalberg 2002; Mrázek 1994). Recently, in rethinking the periodization of Indonesian historiography, the rigidity of the division of 1950-1965 into two periods has also begun to be reassessed (Vickers 2008).

It is worth recalling some of the major events and underlying currents of the 1950-1965 period, such as anti-centrist discontent and political factionalism within Indonesia, international Cold War tensions and the anti colonial struggle in Africa and Asia, all of which both support and modify the delineation of this era of Indonesia's 
history into two distinct periods. Even before the December 1949 transfer of sovereignty, centrifugal tensions (political, religious and regional) were evident. In the midst of the revolution, the communist uprising in Madiun in September 1948 pitched pemuda against pemuda and shattered the image of a united front of independence fighters battling the Dutch. ${ }^{9}$ In August 1949, just four months before the official transfer of sovereignty, the Darul Islam movement proclaimed the establishment of the Indonesian Islamic State based in West Java. (Rebels began to surrender in 1957, but the leader, Kartosuwirdjo, was not captured until 1962). In the early 1950s, rebellions became regional. In April 1950, separatists in Maluku declared the Republic of South Maluku, and in September 1953, there was rebellion in Aceh. In the same year, Kahar Muzakkar, the leader of a rebellion in South Sulawesi that had broken out in 1951, declared this rebellion to be linked to the Darul Islam movement. In December 1956, army officers took over control of civilian government in the provinces of West and North Sumatra, and called for greater regional autonomy. The call was taken up in early 1957 by further army councils established in Kalimantan, North and South Sulawesi and Maluku, and unrest in South Sulawesi escalated in March 1957 with the declaration of the Charter of Universal Struggle (Piagam Perjuangan Semesta Alam, known as Permesta). Martial law was declared. Just over one year later, in March 1958, the Revolutionary Government of the Republic of Indonesia (Pemerintah Revolusioner Republik Indonesia, PRRI) proclaimed its existence in Padang, West Sumatra, leading to a state of civil war. In 1958, the unitary archipelagic state seemed to be falling apart.

As Gusti Asnan and co-authors have discussed, these regional rebellions were not all truly separatist movements, but they were fuelled by discontent with inequitable distribution of wealth (as the national economy spiralled downwards and inflation soared), and by demand for more autonomy in controlling local resources as long-neglected local infrastructure crumbled (Gusti Asnan et al. 2006). By 1960, the military had largely won the regional battle. Now the fight for resources in the national political arena - namely for Soekarno's patronage and the power that ensued - intensified. Between 1957-1960, Soekarno increased his own power over the elected parliament. In 1957, he announced his proposal for 'Guided Democracy' which was fully implemented in 1959, a form of government based on 'mutual cooperation' and more in tune with his view of the Indonesian national character (Ricklefs 2001:309). He consolidated competing power blocks, and enforced

9 See Dharta (writing under pseudonym Jogaswara) 1949. 
political cohabitation between them with his policy of 'Nasakom' the alliance of nationalism, (nasionalisme), religion (agama) and communism (komunisme). In 1960, Soekarno dissolved parliament.

Events in Indonesia were played out against the international backdrop of the Cold War and decolonization in Asia and Africa. Indonesia's communist party was then the third largest in the world after the USSR and the People's Republic of China, (Ricklefs 2001:327). Indonesia, unlike Vietnam for instance, was not a communist state (the Indonesian Communist Party was one party in parliament), yet it was linked into the international network of socialism and Indonesian links to the socialist world were not the monopoly of communists or even of leftist individuals and organizations. Indonesia was a site of competition for influence between the First and Second World superpowers, the US and the USSR, and later, with the Sino-Soviet split in 1961, the USSR, PRC and US. As the first Asian nation to declare its independence at the end of World War II, Indonesia was seen in the region as the leader in the fight against imperialism. Between 1950 and 1965, five Asian and 35 new African nations emerged from previous colonies. ${ }^{10}$ Soekarno was quick to seize leadership in this New World, hosting the first historic Asia Africa meeting in Bandung in 1955, and recognizing the potential power of a neutral third force - a Third World - that could balance the two superpowers and their allies in the Cold War. With so many new African and Asian nations now eligible for membership at the United Nations, the Afro-Asian bloc was a growing political force to be reckoned with.

Over the 1950s, Indonesia opened diplomatic missions over the world, and Soekarno made frequent state trips abroad, travelling to the socialist bloc, the United States, the People's Republic of China, Japan, Southeast Asia, the Middle East and Africa. He was masterful at using the Cold War for his own purposes, playing one superpower off another to obtain foreign aid. It was only in early 1965 , in protest at Malaysia being given a non-permanent seat in the Security Council during Indonesia's Confrontation with what Soekarno saw as a British colonial puppet state, that Indonesia withdrew from the United Nations, Indonesia finally turned its back on the US and its allies and veered more sharply to the left, away from its more neutral stance, and into closer alliance with the PRC.

10 Cambodia (1953); Laos (1954); Sudan, Tunisia, Morocco (1956); Ghana (1957); Malaya (1957) - later Malaysia (1963); Guinea (1958); Chad, Benin, Niger, Nigeria, Ivory Coast, Madagascar, Central African Republic, Mali, Senegal, Burkina Faso, Mauritania, Togo, Zaire, Somalia, Democratic Republic of the Congo, Republic of the Congo, Gabon, Cameroon (1960); Sierra Leone, Syria (1961); (South Africa but with apartheid, not fully independent, 1961); Algeria, Burundi, Rwanda, Uganda (1962); Kenya, Tanzania (1963); Singapore (1965); Malawi, Zambia (1964); Gambia (1965); Maldives (1965). 
On 18 February 1950 - less than two months after international recognition of Indonesia's independence - a group of artists (writers associated with the weekly journal, Siasat, all men) drew up a Testimonial of Beliefs (Surat Kepercayaan Gelanggang) named Gelanggang after the cultural supplement of the weekly Siasat. It opens with the memorable sentence: 'We are the legitimate heirs to world culture, and we are furthering this culture in our own way.' ${ }^{11}$

There are many points to make about this Testimonial, but here I will make three. First, it is striking that the very opening words of this first statement about Indonesian culture post-December 1949 emphasize a world context. From the outset, the authors of the Testimonial see that Indonesia's national culture project is internationalist, Indonesia placing itself in the world. The declaration oozes self-confidence about the place of Indonesian culture in the world - its artists and thinkers, indeed all Indonesians (the 'we') ${ }^{12}$ are legitimate heirs to world culture - not some bastard progeny who must fight for their rights. And Indonesian culture is clearly seen as in terms of ongoing interaction with the world - it is an inheritance that is being furthered 'in our own way'.

A second point to make about the Testimonial is the fact that a group of cultural figures felt the need to make such a declaration so early in the nation's history. The issue of culture is urgent, and it has an important role to play in the nation. (This had also been signalled by the first Indonesian Cultural Congress held in 1948). This sense of urgency and belief in the important role for culture expressed in the Gelanggang Testimonial, the first of many declarations about culture made over the 1950 s and early 1960 s, persists in later statements made by groups with very different ideas about what form it should take.

The third point to make concerns the people who drafted the Gelanggang Testimonial, for they went on to take different paths, some of which are traced in essays in this volume. The Gelanggang group of writers and painters had been formed in Jakarta

11 'Kami adalah ahli waris yang sah dari kebudajaan dunia dan kebudajaan ini kami teruskan dengan cara kami sendiri.' The English translation of this sentence is my own. The full Indonesian text is presented in Goenawan Mohamad (2002a:85-6, 2002b:203). An English translation of the full text is given in Teeuw (1986, I:127) and another in Goenawan Mohamad (2002b:202-3). The Surat Kepercayaan Gelanggang was published in Siasat/Gelanggang 22-10-1950.

12 Goenawan Mohamad (2002a, 2002b) has also pointed out the significance of the use of the exclusive Indonesian pronoun 'kami' ('we', not including 'you') rather than the inclusive 'kita' (all of us, including 'you'), as indicative of the statement being addressed not to fellow Indonesians, but to the outside world. 
in 1946 during the Revolution years, and in 1950 its members still shared a common vision (Goenawan Mohamad 2002b:202; Heinschke 1996; Foulcher 1993). The main architect of the text was Asrul Sani, then aged 24 and already well known as a writer and dramatist, who became a prominent filmmaker in the $1950 \mathrm{~s}$, and in 1962 was one of the founders of Lembaga Seniman Budayawan Muslim Indonesia (LESBUMI, the Institute of Indonesian Muslim Artists and Cultural Figures), which is discussed by Choirotun Chisaan in this volume. Another member of the core Gelanggang group at this time was Sitor Situmorang, poet and journalist then also aged 24, who in 1959 founded and became head of the Lembaga Kebudajaan Nasional (LKN, Institute for National Culture) that was affiliated with the PNI, which Darma Putra discusses in his essay on LKN in Bali. Three other names deserve mention, because they also recur through the 1950s (and in this book). Rivai Apin, writer and editor then aged 22, who was also a core member of the Gelanggang group, later became a prominent member of LEKRA, and from 1959-1965 served on its central committee. Basuki Resobowo, a painter and writer, who at 33 was more senior to the others in the Gelanggang group and also more on the fringe, became a communist activist and, among other things, in the early 1960s participated as set designer in LEKRA- and PKI- sponsored performances promoting communist policies such as land reform that Michael Bodden discusses in his essay. Another member of the wider Gelanggang-Siasat circle of writers at the time of the drafting of the Testimonial was Pramoedya Ananta Toer, only 25 in 1950 but already a well-published writer, who later in the 1950 s became committed to the Left and in 1959 was elected to the executive board of LEKRA, although he was not a member of that organization (Heinschke 1996:149-51).

On Independence Day, August 17, six months after the Gelanggang Testimonial was signed, LEKRA was established and drew up its first declaration on culture, which was given the Arabic word Mukadimah (for 'preamble'). ${ }^{13}$ This declaration of 1950 (which was subsequently revised in 1955) was drafted by 15 'cultural workers' including the writer A.S. Dharta (LEKRA's first General Secretary) the painter Henk Ngantung (member of the central LEKRA Board), Njoto (who was elected to the PKI Politbureau in 1951),

13 To date, where and when the 1950 Mukadimah text was first published remains unsolved. The 1950 text is reprinted in the appendix in Foulcher (1986:209-18) but this was most likely taken from a publication from the late 1950s. The version that was published in Zaman Baru (no. 3 Bulan Djuni 1956) is the later revised 1955 text. 
and writer Joebaar Ajoeb (general secretary of LEKRA from 1959). While primarily a statement about 'People's Culture' ('Kebudajaan Rakjat') and LEKRA's policy of revolution against feudal and imperialist culture, the declaration also stressed interaction with the world in this struggle. 'The essence of foreign cultures', it says, and 'Indonesian culture from the past' will be 'drawn on critically [...] to raise the standard of the new Indonesian culture, namely the People's Democratic Culture'. ${ }^{14}$ From the outset, Indonesian national culture was thus perceived, even with contrasting ideological approaches, in terms of international interaction.

\section{MODELS OF MODERNITY}

Over the 1950 s and 1960 s, as was the case with other recently decolonized societies in Asia - and would occur in African nations emerging from European colonialism - a self-conscious process of 'decolonizing the mind' was essential for Indonesia's autonomous, postcolonial identity. The reality of the new nation severely jolted the process of rethinking the place of cultural heritage, which had begun decades before. It also heralded a more gradual process of liberation from Dutch colonial - 'orientalist' - constructions of Indonesian culture(s).

Since the 1930s, debate about the future of Indonesian culture had been entangled with ideas of Western (European) technological progress. The 'Great Debate' (Holt 1967) or 'Cultural Polemic' (Achdiat K. Mihardja 1954), as it came to be called, which so engaged intellectuals over the 1930s and 1940s was basically the debate between those who saw the need to discard Indonesia's cultures 'of the past' in the move towards becoming both Indonesian and modern, and those who conversely saw Indonesia's cultures as an emblem of its indigenous identity. The choice came to be described in colonial terms of 'East' versus 'West', with 'the West' representing Europe, the future, education and technological progress, and 'the East' indigenous knowledge and non-Western identity, the past and tradition. The complication of that time (and where the debate lay) was the ambiguous position of 'the West':

14 'Kebudayaan asing akan diambil sarinya dengan cara kritis atas dasar kepentingan praktis dari Rakyat Indonesia. Demikian pula kebudayaan Indonesia kuno tidak akan dibuang seluruhnya, tetapi juga tidak akan ditelan mentah-mentah. Kebudayaan kuno akan diterima dengan kritis untuk meninggikan tingkat Kebudayaan Indonesia baru yaitu Kebudayaan demokrasi Rakyat' (Foulcher 1986:212). (Modern Indonesian spelling in Foulcher.) 
while the nationalist movement was a fight against Western colonialism, many saw the same West as the future. How, then, to support locally distinctive cultural self-confidence? ${ }^{15}$

The situation became much more complex once Indonesia became independent. The challenge facing Indonesian artists and intellectuals in the early 1950s was rethinking what modernity meant. Els Bogaerts' essay in this volume, which traces writing of a prominent group of intellectuals writing in the weekly Mimbar Indonesia reveals how a group of largely Dutch-educated urban intellectuals wrestled with this challenge in the decolonization period of the early 1950s, as they began to prise apart notions of modernity and progress from colonial culture. And at the same time, as Liesbeth Dolk discusses in her essay, the Dutch cultural foundation (Stichting voor Culturele Samenwerking, STICUSA) was actively wooing Indonesian artists in an effort to maintain cultural links with the Netherlands, a project which, as she describes, was destined to fail.

Over the 1950s, the question became more complicated as Indonesia's artists and intellectuals came into contact with various models of modernity, both through links with circuits abroad and through contact with each other at home. New networks and models challenged long held ideas, and the old dichotomy of East versus West became completely outdated. Socialism and capitalism offered two diametrically opposed models of technological advancement and progress, and both the socialist USSR and the capitalist United States were Western. ${ }^{16}$ The two superpowers of the Cold War were two different models of the 'new' West. The USSR was the hub of a socialist cultural network with a hectic calendar of events; arts festivals, study tours, exhibitions, youth festivals and meetings in which Indonesia participated. The word 'youth' was everywhere. In contrast, non-socialist Europe was becoming the crusty 'old' West, the West of colonialism, a discredited model of modernity that seemed neither youthful nor modern.

From the mid-1950s, the PRC emerged as a new model of modernity that was particularly important to Indonesia, for the PRC was the new East, with the speed of its social and cultural transformation inspiring, fascinating and alarming to Indonesian artists and intellectuals, about which Hong Liu (2006) has written. The East

15 For further on the cultural debates and an excellent discussion on cultural policy over the 1950-1965 period, see Tod Jones (2005). For a discussion on art and modernity in relation to Bali, see Vickers (1996).

16 See further the discussion in Westad (2005). 
was rising. Keith Foulcher's essay in this volume, which discusses the ideas of a group of artists, writers and intellectuals who represented the cultural arm of Sutan Sjahrir's Partai Sosialis Indonesia (PSI, Indonesian Socialist Party) writing in the bi-monthly Konfrontasi, and traces their shifting interaction with the world outside, shows the crucial role of China in sharpening the new issue troubling intellectuals by around 1957, namely: whose modernity? Socialism or capitalism? The old question of 'East' or 'West' that still haunted the writers of Mimbar Indonesia just a few years back in 1950, was by now well gone.

The competing 'new West' was the United States, which was the source of Hollywood film and popular music that was eagerly consumed all over Indonesia. (It was only in early 1964 that the Left lobbied for a boycott on US film imports, and finally had Soekarno's ear). Soekarno himself was a great fan of Hollywood film. He and his son Guntur were taken to meet film stars like Roy Rogers when Soekarno visited the US in 1956, and Soekarno visited Hollywood again on his second visit to the US in 1961. As Tony Day cites in his essay, although Soekarno and Eisenhower had no political meeting of minds during the 1956 visit, they did converse about film.

Apart from the 'new West' and the 'new East', older established cultural circuits with which Indonesia had long interacted were also being redefined. The old cultural links in the Malay world between Sumatra and the Malay peninsula, with exchange of performance and literature, continued and expanded in the 1950s and early 1960s, as Marije Plomp notes in her essay, with Singapore and Medan now centres of production for film, music and pulp fiction. In the field of literature, Budiawan shows how Indonesia's links with the Malay Peninsula were unique in that Indonesia was the 'exporter' of culture and the source of inspiration to Malay nationalists across the Malacca Strait.

Egypt, still a centre for Islamic study for Indonesians as it had been for centuries, offered a different image of modernity in the 1950s and early 1960s: a Muslim socialist state under Nasser; a centre of the Pan-Arab movement; and a centre for the production of popular culture (film and music) that was exported to Indonesia. Hairus Salim tracks the journeys of three prominent Indonesian cultural figures, the film-maker Usmar Ismail, the writer Hamka and the writer Bahrum Rangkuti, and their interactions with the Muslim world of Egypt and Pakistan. Their views and impressions were published in Islamic journals in Indonesia, (including Gema Islam and Pandji Masjarakat) and this had important repercussions back home in strengthening a vision for contemporary culture 
acceptable to Indonesian Muslims, which included film, music, literature and drama.

Cultural and intellectual engagement with the world was also an imaginative enterprise, particularly through translation. The importance of translators as a bridge between worlds and conduit of ideas and experiences is often overlooked. Recent scholarship has drawn attention to the vital role of translation throughout Indonesia's history (Chambert-Loir 2009). The 1950-1965 period was a particularly active one for translation. Newspapers and journals flourished in the 1950s (until the shortage of paper began to limit publication) providing a publication outlet for translations, and an arena for discussion of ideas. Maya Liem's essay shows the role of translation as a bridge as Indonesian intellectuals found models of modernity in writing from the USSR, other Western countries, and China, and acted as conduits for these ideas as translators. Liem also discusses the choices that faced translators at the time; how they came to know the languages they translated from, why they translated at all, and how they made their choices of material to translate.

\section{THE FUTURE OF THE PAST}

To be Indonesian in 1950 was to be modern. There was a sense of excitement about the 'newness' of being 'born' as a new nation and people, and the words 'baru' (new), 'lahir' (born/birth) and 'modern' permeate writing of the period. Being Indonesian was to become part of a larger whole, which was not entirely a Renanlike process of 'forgetting', as Goenawan Mohamad (2002b:185) has argued, but also the adoption of something more. As well as (rather than instead of) ones regional self as Javanese, Minang or Batak, one took on a new self as an Indonesian citizen that was shared with fellows from other regions. There remained the question of what to do with cultural forms that were associated with the past, and here the response varied.They could be made 'modern' merely through their adoption by the modern Indonesian nation, modified for the national stage where they were shown in juxtaposition. This was Soekarno's approach, both in the performances he sponsored at home for state events and for the national cultural missions he commissioned to promote Indonesia abroad, as Lindsay's and Durban Ardjo's essays show. In a more conservative rendition, it was also the approach of Indonesia's first minister charged with the culture portfolio (September-November 1945) Ki Hadjar 
Dewantara, who famously stated that Indonesia's national culture should comprise the 'peaks of regional cultures'. ${ }^{17}$

However, art associated with the past and regional selves could also be modernized by being made 'progresif' or 'revolusioner', which was the approach of leftist cultural organizations LEKRA (and its subsidiary organizations) and LKN, as Rhoma Dwi Aria Yuliantri, Michael Bodden and Darma Putra discuss. (Ki Hadjar Dewantara's youngest son, Bambang Sokawati Dewantara, took this different path to that of his father. He worked with LEKRA and was active in developing 'progresif' choreography of traditionbased Javanese dance). Revolutionary messages could be injected into existing popular performance forms - from keroncong music to wayang kulit or ludruk (McVey 1986; Peacock 1968) where local specificity (particularly local language), far from being denied, was actively promoted.

On the other hand, performance forms adopted from Western models offered distinctively 'modern' forms of expression. The scripted Indonesian-language drama that Michael Bodden discusses with regard to LEKRA, the choral singing that was so enthusiastically adopted by the Left that Rhoma Dwi Aria Yuliantri discusses, but which was also generally popular at the time, and the Western music that Els Bogaerts mentions as an important topic of discussion in Mimbar Indonesia, all offered another version of 'modern' art, in the sense of self-consciously adopting non-indigenous 'Western' forms, and thus being potentially more easily national and international.

Indonesian responses to the question of culture and modernity were reflected in different forms of artistic expression. Literature, drama, painting, sculpture and music were forms more easily 'modern' because the newness was inherent in both the form itself (non indigenous) and the language (Indonesian). LEKRA encouraged experimentation in these new forms, but, as mentioned above, was also an enthusiastic supporter of regional arts. The thread linking the two was a focus on anti-elitism and anti-'feudalism'. LEKRA's support was for art of the People, not that of the elite, or popular art forms that depicted 'feudal' values unquestionably. Its mission, apart from making art - both old and new - 'progresif' in terms of its socialist message, was also a particularly local one within the

17 'Kebudajaan Indonesia (Nasional) ialah kebudajaan, jang kini sedangnja kita bangun dan kita susun dari segala sari-sari dan puntjak-puntjak segala kebudajaan Daerah diseluruh kepulauan Indonesia', from the report of Hadjar Dewantara's address at the first national Cultural Congress in 1948 (Ki Hadjar Dewantara 1950:88). See further the discussion in Jones (2005), Chapter 2 and Yampolsky (1995). 
national context: namely, to challenge the idea of Indonesian culture being 'high art', such as Ki Hadjar Dewantara's 'peaks'. LEKRA's championing of art forms of the People (forms that many considered 'lower class' troughs) and push to elevate these to the national stage was a direct challenge to that elitist approach. The injection of progressive messages should be seen as part of that process. As Oey Hai Djoen explained, 'We aimed to bring ketoprak and ludruk to the presidential palace'. They succeeded in this. ${ }^{18}$

Concern about a legitimate place in the modern nation for regional or traditional cultures also shaped the experiences of artists, writers and intellectuals who toured abroad in this period. This is what their curiosity was attuned to. Many performers were impressed with the USSR and PRC's support for and teaching of their 'regional' and 'classical' performance heritage. The USSR's multi-nationality, China's support for its 'classical' arts like Chinese opera (this was pre-Cultural Revolution), and particularly the art schools in both the USSR and PRC made a lasting impact on Indonesian performers who toured there (as the essays by Lindsay and Irawati Durban Ardjo show). Indonesia's first Cultural Mission to China in 1954 included the young contemporary dancers Wisnoe Wardhana and Bagong Kussudiardja from Yogyakarta, both of whom on their return wrote enthusiastic articles about China's support for traditional art forms, including Chinese opera. Impressions were not always positive, as Keith Foulcher shows of the novelist and Ramadhan KH's account of his 1957 visit to the PRC.

The physical and imaginative journeying of writer, dramatist and film-maker Usmar Ismail discussed by Hairus Salim, which took place within the national context of the search for Indonesian Islamic identity that Choirotun Chisaan outlines, provides another snapshot of international exposure to cultural modernity, and its particularly local impact. Having studied film in the United States at UCLA (1952-53), Ismail travelled to Egypt in 1959. He was deeply impressed with Egyptian films made with nationalist themes, and made inquiries about the possibility of Indonesian-Egyptian co-production. His exposure to the modern Muslim cultural force that was Egypt at this time was seminal in his formulation of a role for LESBUMI, established in 1962. But it was the local tensions within

18 Interview with Oei Hai Djoen in July 2008, former member of LEKRA secretariat. A short snippet of a performance of 'Ludruk Surobojo' at the presidential palace is shown in a newsreel held at Arsip Nasional, 'Gelora Indonesia' reel 111 (no date for film, c. mid-1950s). The 'Berita Kebudajaan' section of Budaya 6-5 (May 1957):268 mentions a performance of Ludruk Surabaya at Istana Negara Jakarta and Istana Bogor on 23 and 24 March 1957, which could well be the performance caught on film. 
Indonesia, particularly LEKRA's role by the late 1950s in driving the discussion about ideology, politics and art, that allowed Indonesia's more conservative Muslim elements to accept 'modern' Islamic culture that they would normally oppose, such as film and drama promoted by LESBUMI and Himpunan Seni Budaja Islam (HSBI, Association for Islamic Arts and Culture). It was the local tensions that galvanized them into action, bringing together various Islamic groups and cultural organizations.

All the discussion about cultural direction and the activities of various organizations, though, still needs to be seen in broader perspective of what the majority of Indonesian people were doing; what they were watching, reading, and listening to. We still have little idea about what the cultural life of most ordinary people was like in the 1950s and early 1960s. Being culturally modern was also to participate in new forms of popular entertainment. Jakarta was not yet seen as the single epitome of cosmopolitanism or source of this new entertainment. Marije Plomp's essay on Medan gives a vivid picture of cultural life in the 'capital of pulp fiction', where in the mid-1950s almost half of all publications found throughout Indonesia were printed. Malay, Indian and Hollywood films were standard fare, and Plomp notes that the remarkable level of attendance is revealed by the fact that local taxes on cinema tickets provided one third of the total municipal budget. Earnest discussions about 'national culture' in cultural journals, and debates about ideology seem very far from all this. Barbara Hatley's essay on the vibrant cultural life in Makassar in the 1950s also places the activities sponsored by the cultural organizations there against a broader backdrop of cultural life of the time, which included foreign movies, popular music and radio broadcasts.

Meanwhile, in a small town in East Java, Malang, cultural life of this period was also rich and varied. Melani Budianta's essay focuses on the activities of the Chinese population of that town, drawing heavily on her own personal experience. There was so much going on: ballet classes, wayang orang, ludruk, social clubs and activities sponsored by the cigarette companies, temple festivals, ballroom dancing, visits by international and Indonesian dance groups, Hawaiian bands, and popular drama in Mandarin or Chineseinflected Malay. Competition between political parties and organizations in this period actually fostered cultural activity. Budianta's essay depicts a striking picture of the way different groups in the Chinese community and their activities existed side by side, and of the complexity of the mix of culture and politics, and the tensions that ensued. Cultural activities both cut across political and social differences but also marked them. Her 'social history with small 
caps' shows how important - and neglected - this type of research is, to balance both dominant political perspectives and writing about culture in Indonesia that is based on activities in Jakarta and major centres, or focussed narrowly on national 'highbrow' culture.

Budianta's essay on Malang, Darma Putra's essay on LKN in Bali, Barbara Hatley's essay on Makassar and Marije Plomp's on Medan together show the need for more study that looks beyond Jakarta and Java for cultural history of this period. The conflicts that emerged between cultural factions, which have become accepted lore as 'national', then become more complicated and ambiguous. On the one hand there were crossovers that overrode ideological differences, such as social and cultural activities, clubs and family networks that linked people from different ideological camps; and on the other hand there were ideological links that overrode other differences, for instance in Bali, political ideology over-riding differences of caste, or in Java, Islamic groups uniting as a cultural front to counteract leftist and communist cultural strength. It becomes clear that ideological conflict was very much entwined with regional conflicts and differences and varied from place to place, and from time to time. Thus Darma Putra shows that in Bali, where the Muslim element did not exist, the major contest was between two groups that in Java were more closely linked, namely between the PNI's Institute of National Culture (LKN) and LEKRA. On the other hand, Barbara Hatley's essay shows that in Makassar, in the field of drama at least, LEKRA was not so much at the forefront of the cultural contest in the late 1950s and early 1960s, and the main cultural rivalry was between two Muslim groups, the Muhammadiyah-linked ISBM and NU-aligned LESBUMI. Marije Plomp's essay on Medan reveals that there, the contest was more one between cosmopolitan regionalism and Jakarta, rather than LEKRA versus non Left-leaning cultural groups. In all these places - Malang, Makassar, Bali and Medan - local cultural contestations were played out within new sense of national identity that was sensed regionally. ${ }^{19}$

FURTHER CHALLENGES

Contributors to this volume set out to look at the 1950-1965 period afresh. Guiding principles included the agreement to seek out new

19 There are many resonances here with the complicated political expressions of regional identity of this time discussed in Gusti Asnan et al. (2006). 
data, to avoid writing on subjects already relatively well covered (literature, for instance), to pay particular attention to the juxtaposition of and connections between cultural ideas and organizations and interaction between international and national activity, and to areas outside of Jakarta and Java. The writers shared data, communicated during their writing and revisions, and translated each other's papers. Inevitably, though, such an ambitious project has shortcomings. Many 'holes' became apparent as the research progressed, where new questions opened up others that could not be addressed. For instance, the picture of international cultural traffic should be complemented by an essay on the particular cultural image the USSR offered Indonesians at this time. The USSR was the hub of socialism, but it was also, somewhat contradictorily, the hub of Western 'high arts' of ballet and classical music, which many Indonesians studied there, as well as film..$^{20}$ As we proceeded, the importance of the role of Japan also became evident, particularly the links between Japanese communistaffiliated arts groups and artists and organizations in Indonesia, but this too will have to remain a subject for others to pursue.

The subject of popular culture is only touched upon in this volume, but much more needs to be done on Indonesia's production and consumption of popular culture in the 1950s and 1960s, particularly comparing different places in Indonesia. Snippets of information that emerge, such as the remarkably high level of viewing of foreign films (Indian, Malay, Egyptian, as well as American) could be pursued with more detailed study, and so too popular music, comics and pulp fiction. The role of radio is a vitally important and sadly neglected topic and crucial to an understanding of the 1950s and 1960s. The topic of radio emerges everywhere: in overseas broadcasting to Indonesia, as perhaps the single most important conduit of information between Indonesia and the outside world at this time; and in national broadcasting, as the voice broadcasting parts of Indonesia to one other. Difficulty in locating archival material on radio (broadcasts were not recorded, or recordings were not saved) limits research in this area. This is one reason why there is no essay on radio in this volume. ${ }^{21}$ This

20 Henny Saptatia Sujai (documentary film maker and lecturer in international studies) gave a workshop presentation about Indonesian students in the USSR but for family reasons was unable to complete a written essay. However, her interviews with Indonesian alumni of Soviet art schools may yet find form as a documentary.

21 Larisa Efimova gave a presentation on Radio Moscow (where she had worked as translator) at our 2009 workshop in Leiden, in which she pointed out that in Radio Moscow's program 'the Mail Box' received an average of 100 letters per week from listeners from all over Indonesia. However, she was unable to discover further archival holdings in the timeframe of our project to write a contribution for this volume. 
is one of many possible topics for future dedicated research; for instance the Indonesian-language programming of other foreign radio (Radio Beijing; Voice of America; Radio Netherlands; Radio Australia), and the cultural programming of Indonesia's national broadcaster, Radio Republik Indonesia, nationally and at its regional branches.

Visual art is also not discussed in this volume. This was a choice, because although not as consistently discussed as representative of 'culture' in the 1950s and early 1960s as literature, visual art has received more attention than the performing arts or popular culture. Again, though, as this project progressed, the need to bring visual art into the overall discussion became increasingly apparent. A next step might be to take any of the topics in this volume, and broaden them by including visual art (for example, Indonesia's delegations of visual artists and exhibitions overseas; visual art activities of the various cultural organizations, activities outside of Java, or relations between visual artists, performers, filmmakers and writers).

Scholars of Indonesian cultural history might also expect there to be in this volume more dedicated essays on LEKRA, which was undoubtedly the most prominent, important and active cultural force of the period. However, while there is a need for much more detailed research into LEKRA's activities, particularly outside of Java (Bodden (2010) has forged a path here in a recent essay on North Sumatra), the essays in this volume attempt to reclaim other organizations and activities virtually forgotten. By depicting a broader cultural picture of the period, one can then see more clearly how LEKRA was forging the way, and driving other groups to address issues of national cultural direction. It is the juxtaposition of positions, ideas and activities that this volume has set out to highlight, and in this way begin to restore a more contextual framework for discussion of any single one of them. In so doing, this project and the discussions behind the essays presented here show that there are many subjects wide open for further research. There is much that can still be done, and much that young Indonesian scholars, in particular, can achieve. The history is still, just, 'touch'able. There are still people to talk to, childhoods to be discussed, and records to be found. There is enormous potential for group research projects; for instance historians, performers and artists together investigating the social and cultural history of a place, and a defined period of time. If this volume inspires such research, even through the topics it has been unable to address, it will have achieved its goal. 
Stephen Greenblatt (et al. 2010) and Frederick Cooper (2005) remind us that writing on 'cultural identity' has for the past two decades or so focussed on non-boundedness, flows, hybridity, contingency and contestedness. Apart from the desire in western academe to break down its own internal boundaries, this trend is also an aspect of wide late twentieth-century optimism about the end of the nation-state.

But the realities - harsh post 11 September 2001 realities perhaps - have shown that the world is not that simple, and that along with global flows, the nation state and other conscious identifications of boundedness have not 'melted into thin global air'. They are alive and well and in constant mutation.

In his recent book, Cultural mobility, Stephen Greenblatt discusses the ongoing impulses of both cultural persistence and cultural change, and most importantly, the dialectic between them. It is this dialectic that he calls cultural mobility, which, he argues, is at the heart of culture and identity, and has ever been so.

Indonesia in the 1950s and early 1960s is a vivid picture of cultural mobility, for the process of cultural formation (the dialectic at work) is transparent. What we see in 1950s Indonesia is awareness of culture as an emergent process, of, magpie-like, taking and shaping from place and time. As the Gelanggang Testimonial put it, 'We are the legitimate heirs of world culture, and we are furthering this culture in our own way.' There was an acknowledgment that there were different ways, but at the same time a common commitment to the 'Indonesian' part, to the sense of becoming in the name of nation. The sense of becoming that is an inherent part of nationalism is entirely linked to the sense of cultural fluidity."

One of the characteristic powers of a culture', Stephen Greenblatt (2010:252) writes 'is its ability to hide the mobility that is its enabling condition'. Cultural life in Indonesia in the 1950s in particular, shows a time of promise when the future seemed full of possibilities. There was exploration and debate, and experimentations with different models of modernity and their juxtaposition. There was lively and at times rancorous discussion about change and the future, in the language of Revolution. There was exploration of different paths, yet all undertaken in the name of the nation. The mobility is not yet hidden.

The Cold War, which has been seen largely as a bi-polar negative force in Indonesian history, also facilitated and opened up access to new networks, new ideas, and new worlds. As the decade 
changed, the health of Indonesia's economy plummeted, with fear of regionalism as rebellions challenged the centre, and as constitutional democracy moved towards authoritarianism, then the Cold War indeed served to cut off this openness. Ideas from a larger world became narrowed into ideologies - and ideologies narrowed to allegiances and camps. But we must not forget the 1950s. This was a time when Indonesia's cultural mobility and cosmopolitanism meant that people with very different agendas and points of view could interact with the outside world and each other in a vibrant and vigorous way. Lessons to be learnt, perhaps, for the present.

\section{REFERENCES}

Achdiat K. Mihardja

1954

Polemik kebudajaan; Pokok pikiran. Tj. ke-3. Djakarta: Perpustakaan Perguruan, Kementerian Pendidikan Pengadjaran dan Kebudajaan (PP dan K). [Balai Pustaka 1661.] [First published 1948.]

Amir Siddharta

2006

S. Sudjojon, Visible soul. Jakarta: Museum S. Sudjojono: Canna Gallery.

Anderson, Benedict R.O’G.

1972

Java in a time of revolution; Occupation and resistance, 19441946. Ithaca: Cornell University Press.

Ariel Heryanto

1999

'Where communism never dies; Violence, trauma and narration in the last Cold War capitalist authoritarian State', International Journal of Cultural Studies 2-2:147-77.

Asnan, Gusti, David Henley, Diks Pasande, Remco Raben and Esther Velthoen 2006

'Nation, region and the ambiguities of modernity in Indonesia in the 1950s', in: Henk Schulte Nordholt (ed.), Indonesian transitions, pp. 115-62. Yogyakarta: Pustaka Pelajar.

Bodden, Michael

'Modern drama, politics, and the postcolonial aesthetics of Left-Nationalism in North Sumatra; The forgotten theatre of Indonesia's Lekra, 1955-65', in: Tony Day and Maya H.T. Liem (eds), Cultures at war; The Cold War and cultural expressions in Southeast Asia, pp. 46-80. Ithaca, NY: Southeast Asia Program (SEAP), Cornell University. [Studies on Southeast Asia 51.] 
Chambert-Loir, Henri (ed.)

2009 Sadur; Sejarah terjemahan di Indonesia dan Malaysia. Jakarta:

Kepustakaan Populer Gramedia (KPG), École Française d'Extrême-Orient.

Cooper, Frederick, with Rogers Brubaker

2005

'Identity', in: Frederick Cooper (ed.), Colonialism in question; Theory, knowledge, history, pp. 59-90. Berkeley and Los

Angeles: University of California Press.

Cribb, Robert

1990

The Indonesian killings 1965-66; Studies from Java and Bali.

Clayton: Centre of Southeast Asian Studies, Monash University.

Dharta, A.S. (writing under pseudonym Jogaswara)

1949 'Angakatan ‘45 sudah mampus', Spektra, October 27.

Dermawan, Agus T. and Astri Wright

2001 Hendra Gunawan; A great modern Indonesian painter. Singapore/Jakarta: Archipelago Press.

Fealy, Greg and Katherine McGregor

2010 'Nahdlatul Ulama and the killings of 1965-1966', Indonesia (Cornell University) 89:37-60.

Feith, Herbert

1962

The decline of constitutional democracy in Indonesia. Ithaca,

New York: Cornell University Press.

Foulcher, Keith

1986

Social commitment in literature and the arts; The Indonesian 'Institute of People's Culture' 1950-1965. Clayton: Southeast Asian Studies, Monash University. [Monash papers on Southeast Asia 15.]

1993 'Literature, cultural politics and the Indonesian revolution', in: D.M. Roskies (ed.), Text/politics in Southeast Asia, pp. 191-220. Athens: Ohio University Center for International Studies.

Goenawan Mohamad

2002a Eksotopi; Tentang kekuasaan, tubuh dan identitas. Jakarta: Grafiti.

2002b 'Forgetting; Poetry and the nation, a motif in Indonesian literary modernism after 1945', in: Keith Foulcher and Tony Day (eds.), Clearing a space; Postcolonial readings of modern Indonesian literature, pp. 183-212. Leiden: KITLV Press. [Verhandelingen 202.] 
Gouda, Frances with Thijs Brocades Zaalberg

2002

American visions of the Netherlands East Indies/Indonesia; US foreign policy and Indonesian nationalism 1920-1949. Amsterdam: Amsterdam University Press.

Greenblatt, Stephen et al. (eds)

2010

Cultural mobility; A manifesto. Cambridge: Cambridge University Press.

Heinschke, Martina

1996 'Between Gelanggang and Lekra; Pramoedya's developing literary concepts', Indonesia 61:145-69.

Hersi Setiawan

1995

'Art and entertainment in the New Order's Jails (translated and introduced by Keith Foulcher)', Indonesia (Cornell University) 59:1-20. [Published under name Hersi.]

2003 'Tentang Lekra' in: Hersi Setiawan and Islah Gusmian (eds), Aku eks Tapol, pp. 363-79. Yogyakarta: Galang Press.

Holt, Claire

1967

Art in Indonesia; Continuities and change. Ithaca: Cornell University Press.

Jones, Tod

2005

Indonesian cultural policy, 1950-2003; Culture, institutions, government. PhD thesis, Curtin University of Technology, Perth.

Ki Hadjar Dewantara

1950

'Kebudajaan dan pendidikan', Indonesia, (special issue ' $\mathrm{No}$ mor Kongres') 1-1/2 (July-August):87-90.

Liu, Hong

2006

'The transnational construction of "national allegory": China and the cultural politics of postcolonial Indonesia', Critical Asian Studies 38-3:179-210.

McVey, Ruth

1986

'The wayang controversy in Indonesian communism', in: Mark Hobart and Robert H. Taylor (eds), Context meaning and power in Southeast Asia, pp. 21-51. Ithaca: Southeast Asia Program, Cornell University.

Maier, H.M.J.

1987

'Chairil Anwar's heritage; The fear of stultification - another side of Indonesian literature', Indonesia (Cornell University) 43:1-29. 
Mrázek, Rudolf

1994 Sjahrir, politics and exile in Indonesia. Ithaca, NY: Southeast Asia Program, Cornell University.

Nani Nurani Affandi

$2010 \quad$ Penyanyi istana; Suara hati penyanyi kebanggan Bung Karno. Yogyakarta: Galangpress.

Peacock, James L.

1968 Rites of modernization; Symbols and social aspects of Indonesian proletariat drama. Chicago: University of Chicago Press.

Reid, Anthony J.S.

1974 Indonesian national revolution 1945-50. Hawthorn: Longman Australia.

Ricklefs, M.C.

2001

A history of modern Indonesia since c. 1200. Basingstoke: Palgrave.

Roosa, John

2006

Pretext for mass murder; The September $30^{\text {th }}$ movement and Suharto's coup d'état in Indonesia. Madison, WI: The University of Wisconsin Press.

Salim Said

1991

Shadows on the silver screen; A social history of Indonesian film. Jakarta: The Lontar Foundation. [Translated by Toenggoel P. Siagian.]

Sen, Krishna

1994

Indonesian cinema; Framing the New Order. London and New Jersey: Zed Books.

Schulte Nordholt, Henk

2009 'Indonesia's national culture in the 1950s and the death of the citizen'. Paper, Conference Kemerdekaan dan Perubahan Jati Diri/Post Colonial Identity, Yogyakarta, 14-15 January 2010.

Spanjaard, Helena Geertruida

1998 Het ideaal van een moderne Indonesische schilderkunst, 19001995; De creatie van een nationale culturele identiteit. Phd thesis, Rijksuniversiteit Leiden, Leiden.

Taufik Abdullah

2009

Indonesia towards democracy. Singapore: Institute of Southeast Asian Studies.

Teeuw, A.

1986

Modern Indonesian literature, vol. I . Third edition. Dordrecht: Foris Publications. 
Vickers, Adrian

1996

Being modern in Bali; Image and change. New Haven: Yale University Southeast Asia Studies. [Yale Southeast Asia Studies Monograph 43.]

2005

A history of modern Indonesia. Cambridge: Cambridge University Press.

2008 'Mengapa tahun 1950-an penting bagi kajian Indonesia', in: Henk Schulte Nordholt, Bambang Purwanto and Ratna Saptari (eds), Perspektif baru; Penulisan sejarah Indonesia, pp. 67-78. Jakarta: Yayasan Obor Indonesia, Koninklijk Instituut voor Taal-, Land- en Volkenkunde (KITLV) Jakarta, Denpasar: Pustaka Larasan.

Westad, Odd Orne

2005

The global Cold War; Third World interventions and the making of our times. Cambridge: Cambridge University Press.

Wright, Astri

1994

Soul, spirit and mountain; Preoccupations of contemporary Indonesian painters. Kuala Lumpur/New York: Oxford University Press.

Yampolsky, Philip

1995

'Forces for change in the regional performing arts in Indonesia', Bijdragen tot de Taal-, Land-en Volkenkunde 151:700-25. 